\title{
Effects of organic and inorganic fertilization on growth, yield, seed fixed oil content, and fatty acids profile of garden cress (Lepidium sativum L.)
}

\author{
Ebtihal Alsadig Ahmed Mohamed ${ }^{1,2}$ (D) Ali Mahmoud Muddathir ${ }^{1} \cdot$ Abdelwahab Hassan Abdalla $^{3}$
}

Received: 3 July 2020 / Accepted: 21 September 2020 / Published online: 30 September 2020

(c) Springer Nature Switzerland AG 2020

\begin{abstract}
In the present study, a field experiment was conducted for two consecutive seasons (2016/2017 and 2017/2018). The effects of organic and inorganic fertilization on growth, seed yield, seed fixed oil yield, and fatty acid profile of garden cress (Lepidium sativum L.) were investigated under conditions of Khartoum State, Sudan. In each season, the experiment was laid out in a randomized complete block design with four replications. Four fertilizer treatments were used; these were chicken manure at a rate of 11.9 tonha $^{-1}$, NPK (15:15:15) at two rates, $476 \mathrm{kgha}^{-1}$ (NPK1), $952 \mathrm{kgha}^{-1}$ (NPK2) as well as the control. Morphometric parameters, yield components, seed fixed oil content (\%), seed fixed oil yield (tonha ${ }^{-1}$ ), and fatty acids profile were measured. Means were separated using the least significant difference at $p \leq 0.05$ and at $p \leq 0.01$. The difference between chicken manure, NPK1, and NPK2 was not significant $(p \leq 0.05)$ in both seasons, for plant height and 1000-seed weight. However, it was significant $(p>0.05)$ with chicken manure in both seasons for the number of leaves $(831.7,684)$, the number of branches $(144.8,128.5)$, fresh weight $(57.74,61.25)$, and dry weight $(6,7.7)$. The NPK2 treatment significantly $(p \leq 0.05)$ increased the number of capsules $\left(339.5,308\right.$ tonha $\left.^{-1}\right)$, seed yield $(5.51,4.8$ tonha $\left.{ }^{-1}\right)$, seed fixed oil content $(25.65 \%, 25 \%)$, and seed fixed oil yield $\left(1.4,1.1\right.$ tonha $\left.{ }^{1}\right)$ compared to the control in both seasons. The oil profile was affected by all fertilizer treatments. Acoordingly, it can be concluded that using fertilizer is recommended for improvement of growth, seed yield, and oil yield, and quality of L. sativum.
\end{abstract}

Keywords Lepidium sativum L. · Chicken manure · Inorganic fertilizer · Oil profile · Sudanese medicinal plants

\section{Introduction}

Lepidium sativum L., named as garden cress, is an edible annual herb belonging to the Brassicaceae family. It is a fastgrowing herb native to Egypt and Southwest Asia. Locally, it is known as "hab alrashad". It has been cultivated since a very early time in North America, India, and some parts of Europe as a salad and spice [5]. It is distributed in central Sudan [9]. The seed contains edible fixed oil, which is rich in medicinal properties. It also includes a considerable amount of essential oil, amino acids, minerals, and fatty acids. In addition, the seed contains flavonoids, mucilage, coumarins, sulfur glycosides, triterpenes, sterols, natural antioxidants, imidazole alkaloids, glucosinolates, and tannins [1,20,29]. Garden cress is widely used in folk medicine for the treatment of respiratory diseases, liver disease, antimicrobial, anti-inflammation, jaundice, anti-diabetic, gastrointestinal disorders, menstrual problems, bone fractures, osteoarthritis, spleen diseases, muscular pain, and kidney problems $[8,14,17]$. El Ghazaliet al. [8] reported that in Sudan, garden cress had been used for wound treatment and gastrointestinal disorders. Garden cress seeds contain $20-27.5 \%$ oil, which is

$\triangle$ Ebtihal Alsadig Ahmed Mohamed, ebtihalamohamed@gmail.com | 1 Department of Horticulture, Faculty of Agriculture, University of Khartoum, 13314 Shambat, Khartoum, Sudan. ${ }^{2}$ Horticultural Crops Research Center, Agricultural Research Corporation, 30 Shambat, Khartoum, Sudan. ${ }^{3}$ Department of Agronomy, Faculty of Agriculture, University of Khartoum, 13314 Shambat, Khartoum, Sudan. 
relatively stable due to the presence of phytosterols and the high concentration of antioxidants [3, 22]. Alqahtani et al. [3] stated that $L$. sativum seed oil showed a high potentiality of reducing lymphocyte reproduction and the production of inflammatory mediators. Umesha and Naidu [30] demonstrated that feeding of rats with garden cress seed fixed oil, and garden cress seed fixed oil blended with other oils significantly increased it's antioxidant enzymes. Garden cress seed fixed oil contains a high amount of cis-10-heptadecenoic acid, which is reported as an anticancer [28]. The effects of fertilization on plant growth are due to the vital role of nitrogen, phosphorus, and potassium in plant tissues, which reflect on its vegetative growth. They play a critical role in photosynthesis, carbohydrate transport, protein formation, control of ionic balance, regulation of plant stomata, water use, activation of plant enzymes, and other processes [11]. There have been few investigations on the effect of sowing date and planting spacing on garden cress in Sudan and no information about the impact of fertilization. Therefore, the objective of this study was to explore the effect of organic and inorganic fertilization on plant growth, seed yield, seed oil yield, and fatty acid of garden cress under the environmental conditions of Khartoum State, Sudan.

\section{Materials and methods}

\subsection{Location and climate conditions of the experiment site}

A field experiment was carried out in the Experimental Farm of the Department of Horticulture, Faculty of Agriculture, University of Khartoum, Khartoum North (Shambat), Sudan, during two successive winter growing seasons in 2016/2017 and 2017/2018 (December 2016 to March 2017 and December 2017 to March 2018).

The experiment is located at latitude $15^{\circ} 40 \mathrm{~N}$ and longitude $32^{\circ} 32 \mathrm{E}$. The climate is semiarid, tropical with a seasonal annual rainfall of $150-180 \mathrm{~mm}$. The highest temperature is $41.6^{\circ} \mathrm{C}$, and the lowest is $14.1^{\circ} \mathrm{C}$. Soil type is clay loamy with relatively high clay content [2]. Soil analyses are recorded in Table 1. The climate conditions (temperatures and relative
Table 2 Averages of some meteorological data at Shambat during the experimental period (2016/2017 and 2017/2018)

\begin{tabular}{lllll}
\hline Month & $\begin{array}{l}\text { Maximum } \\
\text { temperature } \\
\left({ }^{\circ} \mathrm{C}\right)\end{array}$ & $\begin{array}{l}\text { Minimum } \\
\text { Temperature } \\
\left({ }^{\circ} \mathrm{C}\right)\end{array}$ & $\begin{array}{l}\text { Tempera- } \\
\text { ture mean } \\
\left({ }^{\circ} \mathrm{C}\right)\end{array}$ & $\begin{array}{l}\text { Relative } \\
\text { humidity } \\
(\%)\end{array}$ \\
\hline $\begin{array}{l}\text { December } \\
2016\end{array}$ & 33.4 & 17.5 & 25.4 & 34 \\
$\begin{array}{l}\text { January } \\
2017\end{array}$ & 33.4 & 18.8 & 26.1 & 24 \\
$\begin{array}{l}\text { February } \\
2017\end{array}$ & 31.5 & 16.6 & 24.05 & 16 \\
$\begin{array}{l}\text { March 2017 } \\
\text { December } \\
2017\end{array}$ & 36.4 & 20.2 & 28.3 & 11 \\
$\begin{array}{c}\text { January } \\
\text { 2018 }\end{array}$ & 29.4 & 20.2 & 26.9 & 29 \\
$\begin{array}{c}\text { February } \\
2018\end{array}$ & 36.9 & 15.4 & 22.4 & 20 \\
\begin{tabular}{l} 
March 2018 \\
\hline
\end{tabular} & 38.4 & 21.2 & 29.05 & 20 \\
\hline
\end{tabular}

Source: Ministry of Environment, Natural Resources and Physical Development Meteorological Authority Computer Center (2016/2017 and 2017/2018)

humidity) at Shambat during the experimental period are recorded in Table 2.

\subsection{Experimental design}

The experiment consisted of four treatments arranged in a randomized complete block design with four replicates. The treatments were organic fertilizer and two levels of NPK, as follows: no fertilization (control), organic fertilizer (chicken manure at the rate of 11.9 ton ha ${ }^{-1}$ was applied 15 days before setting up the experiment and irrigated twice), NPK (15:15:15) at the rate of $476 \mathrm{~kg} \mathrm{ha}^{-1}$ (NPK1), applied at planting and NPK (15:15:15) at the rate of $952 \mathrm{~kg} \mathrm{ha}^{-1}$ (NPK2). The treatment (NPK2) was used in split dose with half of the amount $\left(476 \mathrm{~kg} \mathrm{ha}^{-1}\right)$ at planting and the other half $\left(476 \mathrm{~kg} \mathrm{ha}^{-1}\right) 30$ days after planting. Chicken manure analysis is recorded in Table 3.
Table 1 Soil properties of the experimental area

\begin{tabular}{|c|c|c|c|c|c|c|c|c|c|c|}
\hline \multicolumn{3}{|c|}{$\begin{array}{l}\text { Particle size distribution } \\
\text { (\%) }\end{array}$} & \multirow[t]{2}{*}{$\mathrm{pH}$} & \multirow[t]{2}{*}{$\mathrm{EC}(\mathrm{dS} / \mathrm{m})$} & \multicolumn{4}{|c|}{ Soluble cations $(\mathrm{mmol} / \mathrm{l})$} & \multirow[t]{2}{*}{$\mathrm{P}(\%)$} & \multirow[t]{2}{*}{$\mathrm{N}(\%)$} \\
\hline Sand & Silt & Clay & & & $\mathrm{Na}$ & $\mathrm{K}$ & $\mathrm{Ca}$ & $\mathrm{Mg}$ & & \\
\hline 19.7 & 26.2 & 54.1 & 7.54 & 0.7 & 2.8 & 0.34 & 3.3 & 1.3 & 0.80 & 0.03 \\
\hline
\end{tabular}


Table 3 Chemical analysis of chicken manure

\begin{tabular}{lllllllll}
\hline M.C $\%$ & Ca $\%$ & Mg $\%$ & Na $\%$ & K $\%$ & P $\%$ & $\mathrm{~N} \%$ & O.C $\%$ & O.M \% \\
\hline 4.71 & 5.45 & 0.12 & 0.76 & 0.52 & 0.527 & 2.87 & 15.0 & 25.8 \\
\hline
\end{tabular}

Fertilizer sample was analyzed in laboratory of Department of Soil Science, Faculty of Agriculture, University of Khartoum

M.C moisture content, O.C organic carbon, O.M organic matter

\subsection{Land preparations}

The experiment was conducted in an area of $416.25 \mathrm{~m}^{2}$, which was plowed, harrowed, leveled, ridged, and divided into 16 plots. The individual plot size was $17.5 \mathrm{~m}^{2}(5 \mathrm{~m} \times$ $3.5 \mathrm{~m}$ ) comprised of four ridges, each $4 \mathrm{~m}$ long, and $0.7 \mathrm{~m}$ between ridges oriented in east-west direction. The seeds of garden cress used in this experiment were obtained from the local market (Khartoum North market).

Garden cress seeds were sown on December 14th, in each season, in holes at a plant spacing $30 \mathrm{~cm}$ on one side of the ridge (the northern side). The experimental field was irrigated on a weekly basis. Thinning was carried out 30 days from sowing, and three plants per hole were left. Weeding is done weekly. Mature garden cress plants were harvested in March, and the crop was harvested manually. Capsules were separated from straw and weighted in the field, and samples were collected for further analysis.

\subsection{Data collection}

\subsubsection{Morphometric parameters}

Plant height $(\mathrm{cm})$, the number of leaves/plant, the number of branches/plant, fresh weight of the plant $(\mathrm{g})$, and dry weight of the plant $(\mathrm{g})$ were estimated by taking ten plants randomly from each experimental unit (plot) at the age of six weeks from planting.

\subsubsection{Yield components}

After three months from growing, when capsules matured, the following data were recorded:

2.4.2.1 Number of capsules/plant The number of capsules per plant was recorded as the average of ten plants randomly selected from each plot.

2.4.2.2 1000-Seed weight (g) 1000-seed weight was determined on a random sample of 1000 seed obtained from the harvested seeds.

2.4.2.3 Seed yield (ton ha ${ }^{-1}$ ) An area of $1 \mathrm{~m}^{2}$ was harvested randomly after maturity from each plot. For the determination of the seed yield, the whole plants from the harvested area were collected, threshed, sieved, and weighed, and the seed yield per hectare was then determined.

2.4.2.4 Seed fixed oil content (\%) Seed fixed oil was extracted by hexane using the cold method according to [16]. Sixty grams of seeds (three samples from each treatment) were crushed and weighted. The powder was transferred to a glass container, and n-hexane was added in a ratio of 10:1 volume/weight $(\mathrm{v} / \mathrm{w})$. The mixture was stranded for $48 \mathrm{~h}$ in the dark at room temperature. The mixture was then filtered using a standard filter paper (Whatman No. 2, England), and the solvent was removed from the oil using a rotary evaporator. Oil weight was recorded in grams, and the seed oil content was determined as a percentage based on initial seed weight, as follows: seed fixed oil content (\%) was determined by dividing the weight of fixed oil by the weight of the sample multiplied by 100 .

2.4.2.5 Seed fixed oil yield (ton ha ${ }^{-1}$ ) Seed fixed oil yield per hectare was determined by multiplying the oil content (\%) by the seed yield per hectare divided by 100 .

\subsubsection{Fatty acid profile}

In order to analyze the fatty acids profile of garden cress seed oil, at first, their methyl esters derivatives have been prepared. Preparation of fatty acid methyl ester (methylation process). Fatty acids methyl esters were prepared according to [7] method. The samples were prepared by dissolving one milliliter of oil from each sample in roundbottomed flasks $(100 \mathrm{ml})$ in six milliliters of $0.5 \mathrm{M} \mathrm{NaOH}$ (methanolic) and shaken well; then, six milliliters of $1 \%$ methanolic sulfuric acid $\left(\mathrm{H}_{2} \mathrm{SO}_{4}\right)$ were added and shaken well. After that, the mixture was left overnight at $50^{\circ} \mathrm{C}$. Two milliliters of $n$-hexane were added and shook. Then, saturated sodium chloride was added to the level of the neck flask. One milliliter of the upper layer was taken into a glass stoppered tube. Then, anhydrous sodium sulfate was added to remove the moisture. The top n-hexane phase was transferred into a vial and injected into the Gas Chromatography equipped with the capillary column. Garden cress seed fixed oil was analyzed using gas chromatography apparatus (Japan) (Shimadzo GC-2010) 
with DB-1 column (length $30.0 \mathrm{~m}$, diameter $0.25 \mathrm{~mm}$, thickness $0.25 \mu \mathrm{m}$ ). N2/air was used as a carrier gas. The oven temperature program had an initial temperature $100{ }^{\circ} \mathrm{C}$ and a maximum temperature $300^{\circ} \mathrm{C}$ (fatty acids profile was analyzed in Central Laboratory, Faculty of Science, University of Khartoum).

\subsection{Data analysis}

The analysis of variance (ANOVA) was used to determine the effects of treatments on the generated data. The least significant difference was used to test the differences between means at $p<00.05$ and $p<0.01$.

\section{Results}

\subsection{Morphometric parameters}

\subsubsection{Plant height $(\mathrm{cm}) /$ plant}

Results in Table 4 show that plant height was not significantly $(p<0.05)$ affected by fertilization treatments in both seasons. The highest values were recorded for chicken manure (59.80 and 63.87), followed by NPK1 (59.23 and 57.40), NPK2 (57.22 and 55.90), and then the control (56.88 and 55.10) in both seasons, respectively.

\subsubsection{The number of leaves/plant}

All fertilization treatments increased the number of leaves highly significant $(p<0.01)$ in both seasons, comparing with the control (Table 4). Chicken manure fertilization resulted in the highest values (831 and 684, in the first and the second season, respectively), followed by NPK2
(774.65 and 508.82), and then NPK1 (730.12 and 411.35). In contrast, the lowest values (322 and 208, respectively) were recorded for the control in both seasons.

\subsubsection{The number of branches/plant}

The number of branches increased for all fertilization treatments comparing with the control (Table 4). The values were highly significant $(p<0.01)$ in the first season and significant $(p<0.05)$ in the second season. Chicken manure resulted in the highest values (144 and 128 in both seasons, respectively), followed by NPK2 (139.07 and 118.37), and NPK1 (123.47 and 113.41), while the control resulted in the lowest values (88 and 68).

\subsubsection{Plant fresh weight $(\mathrm{g})$}

Results on fresh plant weight are presented in Table 4. They indicated that there were highly significant $(p<0.01)$ differences among the different treatments in both seasons. The highest values were recorded for chicken manure (57 and $61 \mathrm{~g})$, NPK2 (41.57 and 54.77), and NPK1 (42.48 and 37.48), and the lowest values (25 and $22 \mathrm{~g}$ ) were recorded for the control in both seasons, respectively.

\subsubsection{Plant dry weight (g)}

All fertilization treatments increased plant dry weight highly significantly $(p<0.01)$ in both seasons (Table 4$)$. The highest values ( 6 and $7.7 \mathrm{~g}$ ) were recorded for chicken manure followed by NPK2 (04.44 and 06.77) and NPK1 (04.37 and 05.85), whereas the lowest values (2.9 and $2.1 \mathrm{~g}$ ) were recorded for the control in both seasons, respectively. 


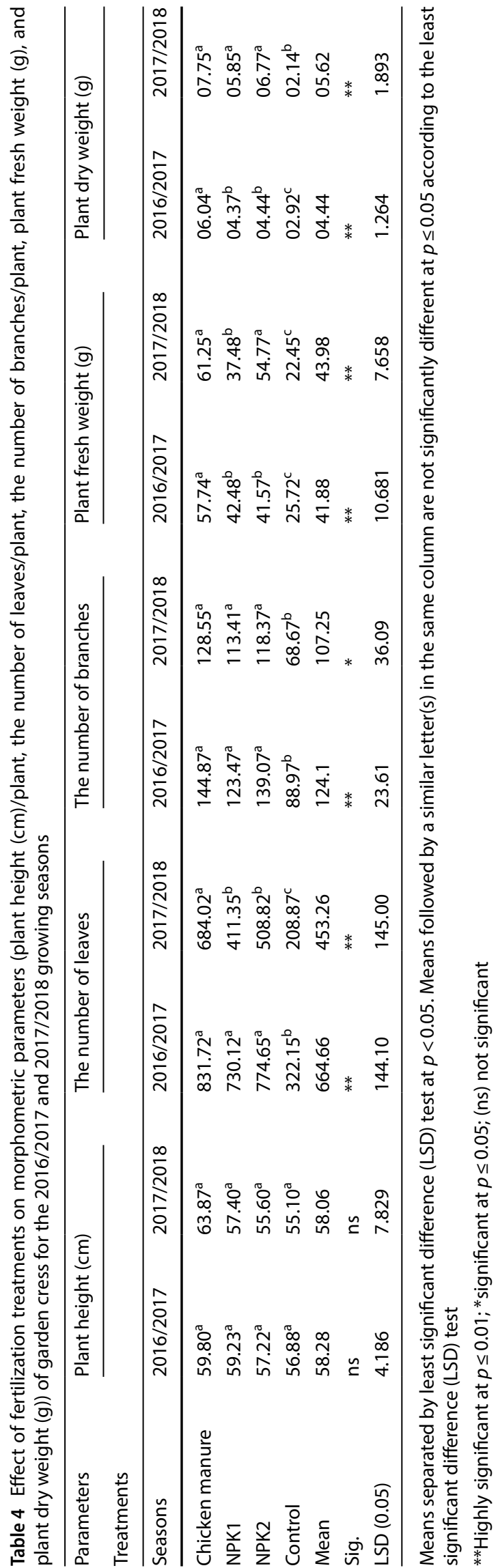

\subsection{Yield components}

\subsubsection{The number of capsules/plant}

Highly significant differences $(p<0.01)$ were displayed among treatments in the number of capsules per plant (Table 5). NPK2 resulted in the highest values (319 and 286), followed by NPK1 (323.47 and 293.75), then the chicken manure ( 319.25 and 286.75$)$, and the control recorded the lowest values (248 and 207) during both seasons, respectively.

\subsubsection{0-Seed weight (g)}

In the present study, results (Table 5 ) showed that 1000seed weight was not significantly $(p<0.05)$ affected by different fertilizer treatments in both seasons. The overall 1000 -seed weight was $1.69 \mathrm{~g}$. NPK2 treatment recorded 1.700 and 1.710, NPK1 treatment recorded 1.697 and 1.695 , chicken manure recorded 1.700 and 1.685 , and the control recorded 1.672 and 1.679 in both seasons, respectively.

\subsubsection{Seed yield (ton ha ${ }^{-1}$ )}

Significant $(p<0.05)$ differences were shown among the different treatments in seed yield per hectare (Table 5). The highest yield resulted from NPK2 (5.5 and 4.8 ton $\mathrm{ha}^{-1}$ ), followed by NPK1 (4.89 and $4.25 \mathrm{ton} \mathrm{ha}^{-1}$ ) and then chicken manure (4.80 and 4.40 ton $\mathrm{ha}^{-1}$ ) and the lowest one ( 2.9 and 2.6 ton ha ${ }^{-1}$ ) from the control in both seasons, respectively.

\subsubsection{Seed fixed oil content (\%)}

Results in Table 5 showed that seed fixed oil content (\%) was highly significant and significantly affected by the different treatments in the first and second seasons, respectively. NPK2 resulted in the highest values $(25.65 \%$ and $25.02 \%)$, followed by NPK 1 (25.00\% and $24.79 \%)$ and chicken manure (24.77\% and $24.74 \%)$, while the control resulted in the lowest values ( $22.17 \%$ and $24.07 \%$ ).

\subsubsection{Seed fixed oil yield (ton $\mathrm{ha}^{-1}$ )}

Highly significant $(p<0.01)$ and significant $(p<0.05)$ differences were detected among the fertilizer treatments in seed fixed oil yield (ton ha ${ }^{-1}$ ) in the first and second season, respectively (Table 5). NPK2 resulted in the highest values ( 1.41 and 1.19 ton ha ${ }^{-1}$ ), followed by (1.22 and 1.03 ton $\mathrm{ha}^{1}$ ) and then chicken manure ( 1.13 and 1.10 ton $\left.\mathrm{ha}^{-1}\right)$, while the control recorded the lowest values $(0.65$ and 0.63 ton $\mathrm{ha}^{-1}$ ). 


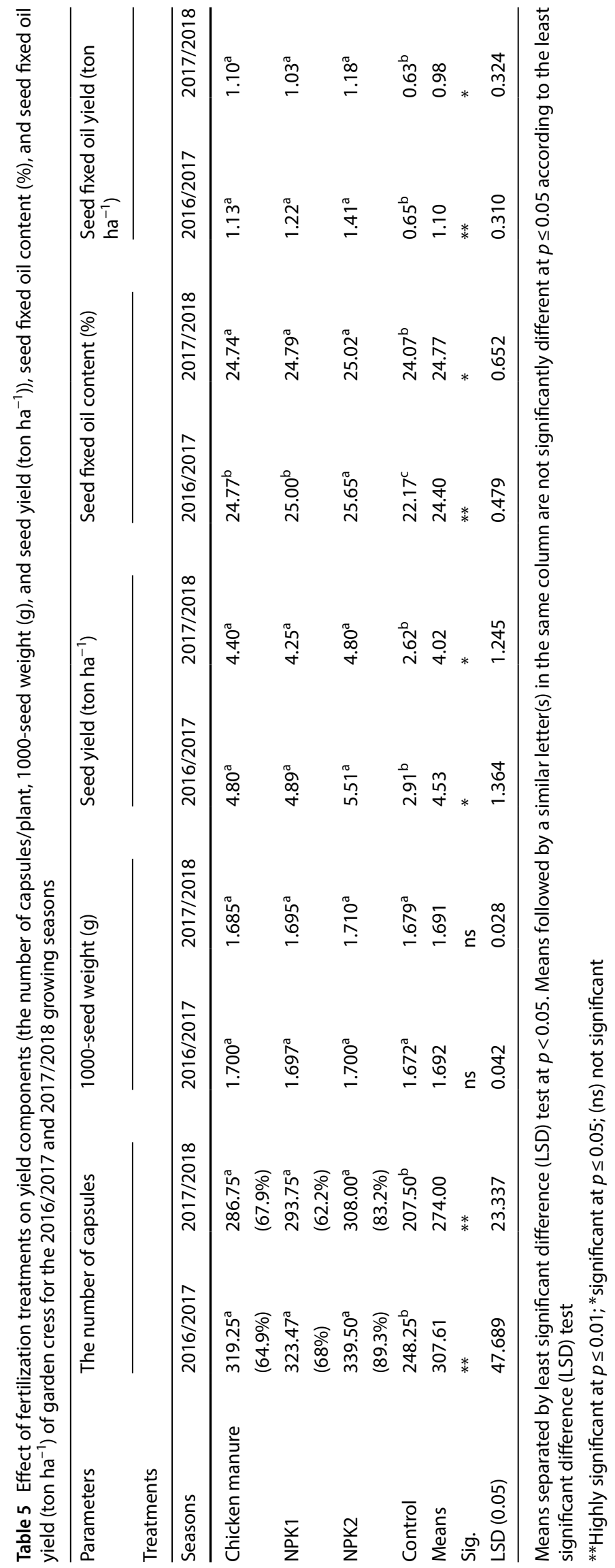


Table 6 Fatty acids composition (\%) of garden cress seed fixed oil affected by the different fertilization treatments for the 2016/2017 and $2017 / 2018$ growing seasons

\begin{tabular}{|c|c|c|c|c|c|c|c|c|}
\hline \multirow[t]{2}{*}{ Fatty acids } & \multicolumn{4}{|c|}{ Season $2016 / 2017$} & \multicolumn{4}{|c|}{ Season $2017 / 2018$} \\
\hline & Control & C. $\mathrm{m}^{*}$ & NPK1 & $\overline{N P K 2}$ & Control & C. $m^{a}$ & NPK1 & NPK2 \\
\hline Pentadecenoic acid & 17.3 & 08.9 & 06.2 & 07.7 & 09.8 & 06.6 & 06.2 & 07.7 \\
\hline Cis-10-heptadecenoic & 67.4 & 65.1 & 62.7 & 66.1 & 60.5 & 00.6 & 64.9 & 66.0 \\
\hline \multicolumn{9}{|l|}{ Acid (margaric acid) } \\
\hline Hexadecanoic acid (palmitic acid) & - & - & - & - & - & 66.4 & - & - \\
\hline Heptadecanoic acid & 15.1 & 03.8 & 02.8 & 00.9 & - & - & 02.80 & 00.9 \\
\hline Stearic acid & - & 12.5 & 17.4 & 15.6 & - & 16.2 & 17.7 & 15.6 \\
\hline Arachidonic acid & - & 05.9 & 07.6 & - & - & - & - & 06.5 \\
\hline Arachidic acid & - & 03.4 & - & 06.5 & - & 0.09 & - & - \\
\hline Cis-13,16-docosadienoic & - & - & 01.6 & - & - & 00.4 & 0.05 & - \\
\hline Elaidic acid & - & - & - & - & 7.7 & - & - & - \\
\hline Cis-11,14-eicosadienoic & - & - & - & - & 21.7 & 7.3 & 8.2 & 0.4 \\
\hline
\end{tabular}

${ }^{*} \mathrm{C} . \mathrm{m} .=$ chicken manure. $-=$ not detected

\subsection{Fatty acids profile}

Data showed that (Table 6) seed fixed oil composition of all treatments showed a similar trend of major fatty acid composition of cis-10-heptadecenoic acid in the first and the second seasons, respectively $(67.4 \%, 65.1 \%, 62.7 \%, 66.1 \%)$ and $(60.5 \%, 0.6 \%, 64.9 \%, 66 \%)$, except for the treatment chicken manure in the second season, where it recorded a trace amount $(0.6 \%)$, and the fatty acid hexadecanoic acid (palmitic acid) appeared and recorded the highest value (66.4\%). Generally, the highest percentage of fatty acid was recorded for the compound cis-10-heptadecenoic acid followed by stearic acid, pentadecenoic acid, heptadecanoic acid, and arachidonic acid. Moreover, stearic acid, arachidonic acid, arachidic acid, and cis-13,16-docosadienoic acid were absent in control treatment in both seasons. In addition, pentadecenoic acid and heptadecanoic acid recorded the highest value in control treatment. Additionally, cis-11,14-eicosadienoic acid was recorded in the second season only at different percentages for all treatments. Regarding elaidic acid, it was recorded in the second season only in the control treatment.

\subsection{The correlation between seed fixed oil content and fatty acids percentage}

Data in Table 7 demonstrated the correlation between the value of the seed fixed oil content and fatty acids. In this study, a high and positive correlation was found between the seed fixed oil content and the content of stearic acid in both seasons ( $r=0.96,0.93$, respectively). In addition, there was a high and positive correlation between seed oil content and arachidic acid in the first season $(r=0.65)$ and a low positive correlation in the second season (0.13). The correlation regarding arachidonic acid was moderately positive in the second season $(r=0.59)$ and low positive
Table 7 Correlation between seed fixed oil content and fatty acid percentage of garden cress under four fertilizer treatments during growing season of 2016/2017 and 2017/2018

\begin{tabular}{lcc}
\hline Fatty acids & $2016 / 2017$ & $2017 / 2018$ \\
\hline Pentadecenoic acid & -0.95 & -0.77 \\
Cis-10-heptadecenoic acid & -0.58 & -0.06 \\
Palmitic acid & 0.00 & 0.13 \\
Heptadecanoic acid & -0.99 & 0.43 \\
Stearic acid & 0.96 & 0.93 \\
Arachidonic acid & 0.37 & 0.59 \\
Arachidic acid & 0.65 & 0.13 \\
Cis-11,14-eicosadienoic & 0.00 & -0.99 \\
\hline
\end{tabular}

in the first season $(r=0.37)$. The correlation between palmitic acid was low positive in the second season $(r=0.13)$. Regarding heptadecanoic acid, the correlation was moderately positive in the second season $(r=0.43)$ and high negative in the first season $(r=-0.99)$. A high negative correlation ( $r=-0.95,-0.77$, respectively) was observed in pentadecenoic acid in both seasons. The association regarding cis-11,14-eicosadienoic acid was highly negative in the second season $(r=-0.99)$. Regarding cis-10-heptadecenoic acid, the correlation was highly negative in the first season $(r=-0.58)$ and low negative in the second season $(r=0.06)$.

\section{Discussion}

The nonsignificant difference among the fertilization treatments indicates that fertilization had no effect on plant height in garden cress. On the other hand, the significant differences in the number of leaves have been detected among the treatments, which indicates that fertilization 
had a positive effect on this parameter. In this study, the effect of chicken manure on the number of leaves was similar to that of the high dose of NPK. A similar pattern was also observed in the case of the number of branches. In addition, the present study confirmed the importance of fertilization on the fresh and dry weights of the garden cress plant. The application of nitrogen increased vegetative growth and so grown plant fresh and dry values. These results are in agreement with [21], who found that the application of organic fertilizer on rape (Brassica napus L.) greatly enhanced fresh and dry weights.

The most important role of nitrogen in plants is accounting a high portion of a protein that is associated with all vital processes in plants, and it considers as the most critical building substances from which the living material or protoplasm of the cell is made. Also, nitrogen occurs in chlorophyll (the green coloring matter of leaves), chlorophyll is essential in photosynthesis process, and it is responsible for vegetative growth. Supplying plants with sufficient nitrogen makes its leaves dark green, and the photosynthesis process can proceed more effectively. Therefore, supplying the plant with nitrogen will increase the amount of protein, chlorophyll formed, and protoplasm. Thus, it increases cell size, leaves production, leaf area, and photosynthetic activity as well as stimulating root growth, which will reflect in high net assimilation rate, consequently high vegetative growth, high plant fresh and dry weights, and high yield and enhance quality [18]. In this study, chicken manure contains $341.5 \mathrm{~kg} \mathrm{~N} / \mathrm{ha}$, whereas NPK2 contains $142.8 \mathrm{~kg} \mathrm{~N} / \mathrm{ha}$ and NPK1 contains $71.4 \mathrm{~kg} \mathrm{~N} / \mathrm{ha}$, so that chicken manure enhanced vegetative growth more than NPK2 and NPK1, and consequently, chicken manure resulted in higher vegetative growth.

In the present study, the significant differences in the number of capsules observed among the treatments reflected the importance of fertilizer application in increasing this parameter. The maximum number of capsules that have recorded to NPK2 therapy can be attributed to rich soil environments because of the presence of sufficient quantities of potassium, which promoted plant vegetative as well as reproductive growth processes. The minimum number of capsules in control might have been due to less availability of nitrogen, phosphorus, and potassium and stunted growth. These results are in line with those of [12] who stated that the application of chemical fertilizers on canola increased the number of capsules compared to the organic fertilizers. However, in this study, 1000-seed weight was not significantly $(p<00.05)$ affected by fertilizer treatments. These results are in agreement with the findings of [6], who stated that 1000-seed weight was more influenced by season variation than fertilization treatment. Angelini et al. [4] reported that the weight of 1000 seed of $L$. sativum varied between 1.6 and $2.2 \mathrm{~g}$. The significant positive effects of fertilizer application on the fresh and dry weights of plants as well as the number of capsules per plant contributed to the substantial increase in seed yield. This indicates that the productivity of the garden cress crop was significantly affected by fertilization. Mineral compound fertilizers were more effective than organic fertilizers. In the present study, NPK2 out-yielded the control, NPK1, and chicken manure by $89.3-83.2 \%$, $68-62.2 \%$, and $64.9-67.9 \%$ in both seasons, respectively. The high seed yield obtained from NPK2 treatment could be attributable to the increase in the number of capsules per plant. These results are in agreement with the finding of [12], who reported that the application of chemical fertilizers on canola significantly increased seed yield compared to the organic fertilizers. In addition, [6] reported that increasing amounts of fertilizer increased the seed yield of rape (Brassica napus L.).

Phosphorus plays a significant role in photosynthesis, respiration, energy storage, and usage, cell division, and maturation. Moreover, it also plays a significant role in roots branching and lateral root morphology and affects root development and root-shoot ratio. Potassium is important in plant metabolism, protein synthesis, and chlorophyll development and improves nitrogen use efficiency; it also plays a major role in nutrients and water transportation, and acquit level of potassium increases the translocation of nitrates, phosphorus, amino acids, magnesium, and calcium [23]. Increasing the rate of potassium fertilizer increased the number of capsules. The higher yield at higher NPK fertilizer levels might have been due to reduced premature drop of flowers and young capsules because of the sufficient amount of phosphorus. This result is in agreement with [24], who reported a significant effect of phosphorus application on the number of capsules per plant and seed yield. The maximum number of capsules noted in NPK2 treatment can be attributed to rich soil environments because of the presence of sufficient quantities of potassium, which promoted plant vegetative as well as reproductive growth processes. This indicates that the productivity of the garden cress crop is significantly affected by fertilization. Not only that, but mineral compound fertilizers were more effective than organic fertilizers. In this study, NPK2 contains $142.8 \mathrm{~kg} \mathrm{P}_{2} \mathrm{O}_{5} /$ ha and NPK1 contains $71.4 \mathrm{~kg}$ for the two $\mathrm{K}_{2} \mathrm{O}_{1} \mathrm{P}_{2} \mathrm{O}_{5} / \mathrm{ha}$. However, chicken manure contains $61 \mathrm{~kg} \mathrm{P}_{2} \mathrm{O}_{5} / \mathrm{ha}$, so that the increment in seed yield and yield components is higher in NPK2 (47.18\%) compared to the control followed by NPK1 (40.49\%) and chicken manure (36.04\%). The seed yield of the garden cress improved with the increase in phosphorus levels due to similar improvement in yield attribute (number of capsules per plant), the highest seed yield was recorded with $142.8 \mathrm{~kg} \mathrm{P}_{2} \mathrm{O}_{5} /$ ha (NPK2) application, and all the phosphorus levels $\left(71.4,61 \mathrm{~kg} \mathrm{P}_{2} \mathrm{O}_{5}\right)$ were significantly 
superior over control. The maximum seed yield obtained from NPK2 treatment could be attributable to an increase in the number of capsules per plant. In addition, [25] reported that increasing amounts of fertilizer increased the seed yield of rape (Brassica napus L.).

An increase in the number of capsules, seed yield, and seed fixed oil contents might have been due to better and balanced nutrient supply, especially phosphorus. Moreover, the higher yield at higher fertilizer levels might have been due to reduced premature drop of flowers and young capsules. Results are in line with those obtained by [15], who reported a significant effect of phosphorus application on the number of capsules plant, seed yield, and seed fixed oil contents. Angelini et al. [4] stated that $1.4,2.2$, and 2.9 tons of garden cress seed yield could be produced from one hectare. It has been reported that $L$. sativum seed contains $20-27.5 \%$ oil $[22,27]$. Seed fixed oil content and seed fixed oil yield followed the same pattern as that of seed yield, indicating the importance of fertilizer application in increasing seed fixed oil content and seed fixed oil yield. These results are in agreement with those of [12], who stated that the application of chemical fertilizers on canola significantly increased seed fixed oil content compared to the organic fertilizers. The increment in oil content with increased whole fertilizer level might have been due to better and balanced nutrient supply, especially phosphorus. Results in this study are in line with those obtained by [15], who reported a significant effect of phosphorus application on seed fixed oil content.

The results of this study indicated that the fertilization treatments greatly affected the fatty acid profile of garden cress seed fixed oil regarding both the presence and percentages of fatty acids. Data showed that some important fatty acids did not present in control treatments and presented in all (sometimes part of) the other fertilization treatments like palmitic acid, stearic acid, arachidonic acid (one of the omega-six family), and arachidic acid and the presence of these fatty acids improves the quality of garden cress seed oil obtained from fertilization treatment. These results are in agreement with those of [10], who stated that fertilization treatments (organic, and inorganic) affected fatty acids presence, percentages, and the ratio of the fatty acids to each other in canola seed oil. The highest rate of the fatty acid composition of garden cress seed fixed oil was cis-10-heptadecenoic acid (margaric acid). Many variations were reported by different researchers. Alqahtani et al. [3] reported that significant constituents found in garden cress seed fixed oil obtained from Saudi Arabia were 7,10-hexadecadienoic acid, 11-octadecenoic acid, 7,10,13-hexadecatrienoic acid, and behenic acid amounting $44.37 \%, 15.50 \%, 9.93 \%$, and $9.67 \%$, respectively. Moreover, [27] reported that fatty acid profile of garden cress seed fixed oil obtained from Ethiopia was 11, 13 docosadienoic acid, 9,12-octadecanoic acid, 11-eicosanoic acid, and palmitic acid $(47.66 \%, 11.51 \%, 10.63 \%$, and $10.13 \%$, respectively). Such variation in oil composition suggested a possible effect of fertilizer type (organic vs. inorganic) and a growing environment. Arachidonic acid is one of the omega-six family, which is considered essential since human metabolism is unable to synthesize them, and they should therefore be added to the diet to prevent the attenuation of a host of diseases [26]. In the present study, the highest concentration of arachidonic acid (7.6\%) was detected in NPK1 treatment. Zheljazkov et al. [31] demonstrated that agricultural factors such as planting date, hybrid, and nitrogen rate might significantly modify oil content and fatty acids composition. In this study, the fertilization treatments affected the fatty acid presence and percentages. These results are in agreement with those obtained by [13], who reported that using different fertilization treatments changes the fatty acid composition (increasing some fatty acids percentages and reducing some fatty acids percentages in other seasons). Also, he stated that there were a number of factors affected the presence, and the percentages of fatty acids composition in flax, and the highest effects on the fatty acids composition were observed in the effect of fertilization treatments in the second year of research.

The results on fatty acids and seed fixed oil content correlation were in line with that obtained by [24] who reported that there is a high positive correlation between seed fixed oil content, the fatty acid, and stearic acid $(r=0.88)$ in canola. Jogić et al. [13] reported a positive correlation between the total seed fixed oil content and stearic acid $(r=0.852)$ on flax. Also, this result is in agreement with [19], who stated that eicosadienoic acid showed negative correlation $(r=-0.58)$ with seed fixed oil content in rape and radish.

\section{Conclusion}

Application of organic and inorganic fertilizers greatly enhanced growth, seed yield, seed fixed oil content and yield, and affected the fatty acids profile of $L$. sativum $L$. Organic fertilizer (chicken manure) increased the number of leaves, the number of branches, and fresh and dry weights. On the other hand, inorganic fertilizer (NPK) increased the number of capsules, seed yield, seed fixed oil content, and seed fixed oil yield compared to the control in both seasons, while both fertilizer types did not affect the plant height and weight of 1000 seed in both seasons.

Acknowledgements The authors are thankful to Mrs. Suhair Mohamed Al-amin for her valuable assisting in the field work. 


\section{Compliance with ethical standards}

Conflict of interest The authors declare that they have no conflict of interest.

\section{References}

1. Abdelghany AM, Meikhail MS, Abdelraheem GEA, Badr SI, Elsheshtawy N (2018) Lepidium sativum L. natural seed plant extract in the structural and physical characteristics of polyvinyl alcohol. Int J Environ Stud 6:965-977. https://doi. org/10.1080/00207233.2018.1479564

2. Adam HS (1996) Agricultural climate, Dar El-Asalla for information, press and publication, 1st edn, p 112 (in Arabic)

3. Alqahtani FY, Aleanizy FS, Mahmoud AZ, Farshori NN, Alfaraj R, Al-sheddi ES, Alsarra I (2019) Chemical composition and antimicrobial, antioxidant, and anti-Inflammatory activities of Lepidium sativum seed oil. Saudi J Biol Sci 26(5):1089-1092. https://doi. org/10.1016/j.sjbs.2018.05.007

4. Angelini LG, Moscheni E, Colonna G, Belloni P, Bonari E (1997) Variation in agronomic characteristics and seed oil composition of new oilseed crops in central Italy. Ind Crops Prod 6:313-323. https://doi.org/10.1016/S0926-6690(97)00022-8

5. Asad Ullah M, Tungmunnithum D, Garros L, Drouet S, Hano C, Abbasi BH (2019) Effect of ultraviolet-C radiation and melatonin stress on biosynthesis of antioxidant and antidiabetic metabolites produced in In Vitro callus cultures of Lepidium sativum L. Int J Mol Sci 20:1-19. https://doi.org/10.3390/ijms20071787

6. Christen O, Sieling K (1995) Effect of different preceding crops and crop rotations on yield of winter oil-seed rape (Brassica napus L.). J Agron Crop Sci 174:265-271. https://doi. org/10.1111/j.1439-037X.1995.tb01112.x

7. Christie MM (1990) Preparation of methyl esters-part 1. Lipid Technol 2(2):48-49

8. El Ghazali GEB, Khalid HE, El Tohami MS, Abdalla WE, Yagi SMA (1998) Medicinal plants of Khartoum State. National centre for research, Medicinal \& Aromatic plants research Institute, Khartoum

9. El Ghazali GEB, Abdalla WE, El Egami AAB, Al Magboul AZI, Hamad AAD (2004) Aromatic plants of the Sudan. National Centre for Research, Medicinal \& Aromatic Plants Research Institute, Khartoum

10. Gao J, Thelen KD, Min D, Smith S, Hao X, Gehl R (2010) Effects of manure and fertilizer applications on canola oil content and fatty acid composition. Agron J 102:790-797. https://doi. org/10.2134/agronj2009.0368

11. Gross AA, Nejidat AR (2007) Assessment of extraction methods with fowl manure for the production of liquid organic fertilizers. Bioresour Technol 99:327-334

12. Javaheri M, Shiranirad AH, Daneshian J, Amiri E, Saifzadeh S (2014) Effect of planting time and the use of fertilizer on canola yield and yield components. Int J Agric For 4(4):293-299. https ://doi.org/10.5923/j.ijaf.20140404.05

13. Jogić V, Džafić S, Nikitović J (2018) Effects of fertilization on the fatty acid content of oil flax. Int J Adv Agric Sci Technol 5(12):21-27

14. Karole S, Shrivastava S, Thomas S, Soni B, Khan S, Dubey J, Dubey SP, Khan N, Jain DK (2019) Polyherbal formulation concept for synergic action: a review. J Drug Deliv Ther 9(1-s):453-466. https ://doi.org/10.22270/jddt.v9i1-s.2339

15. Khan NI, Akbar M, Lqbal N, Rasul S (2000) Bioagronomic evaluation of linseed genotypes. Pak J Biol Sci 3(7):1172-1173. https ://doi.org/10.3923/pjbs.2000.1172.1173
16. Kostić MD, Joković NM, Stamenković OS, Rajković KM, Milić PS, Veljković VB (2013) Optimization of hempseed oil extraction by n-hexane. Ind Crops Prod 48:133-143. https://doi.org/10.1016/j. indcrop.2013.04.028

17. Ksoudaa G, Hajjia M, Sellimia S, Merlierb F, Falcimaigne-Cordinb A, Nasria M, Thomassetb B (2018) A systematic comparison of 25 Tunisian plant species based on oil and phenolic contents, fatty acid composition and antioxidant activity. Ind Crops Prod 123:768-778

18. Leghari SJ, Wahocho NA, Laghari GM, HafeezLaghari A, MustafaBhabhan G, Talpu KH, Bhutto TA, Wahocho SA, Lashari AA (2016) Role of nitrogen for plant growth and development: a review. Adva Environ Biol 10(9):209-218

19. Mandal S, Yadav S, Singh R, Begum G, Suneja P, Singh M (2002) Correlation studies on oil content and fatty acid profile of some Cruciferous species. Genet Resour Crop Evol 49:551-556. https ://doi.org/10.1023/A:1021210800414

20. Matthäus B, Angelini LG (2005) Anti-nutritive constituents in oilseed crops from Italy. Ind Crops Prod 21:89-99. https://doi. org/10.1016/j.indcrop.2003.12.021

21. Mojeremane W, Motladi M, Mathowa T, Legwaila GM (2015) Effect of different application rates of organic fertilizer on growth, development and yield of rape (Brassica napus L.). Int J Innov Res Sci Eng Technol 4:11680-11688. https://doi. org/10.15680/IJIRSET.2015.0412004

22. Moser BR, Shah SN, Winkler-Moser KJ, Vaughn SF, Evangelista RL (2009) Composition and physical properties of cress (Lepidium sativum L.) and field pennycress (Thlas piarvense L.) oils. Ind Crops Prod 30:199-205. https://doi.org/10.1016/j.indcr op.2009.03.007

23. Prajapati K, Modi HA (2012) The importance of potassium in plant growth - a review. Indian J Plant Sci 1(02-03):177-186

24. Sharafia Y, Majidib MM, Golic SAH, Rashidid F (2015) Oil content and fatty acids composition in Brassica species. Int J Food Prop 18(10):2145-2154. https://doi.org/10.1080/10942 912.2014.968284

25. Sieling K, Christen O (1997) Effect of preceding crop combination and $\mathrm{N}$ fertilization on yield of six oil-seed rape cultivars (Brassica napus L.). Eur J Agron 7:301-306. https://doi. org/10.1016/S1161-0301(97)00009-9

26. Simopoulos AP (2002) The importance of the ratio of omega-6/ omega-3 essential fatty acids. Biomed Pharmacother 56:365379. https://doi.org/10.1016/S0753-3322(02)00253-6

27. Solomon G, Aman D, Bachheti RK (2016) Fatty acids, metal composition, nutritional value and physicochemical parameters of Lepidium sativiumseed oil collected from Ethiopia. Int Food Res J 23(2):827-831

28. Srivastava R, Mukerjee A, Verma A (2015) GC-MS analysis of phytocomponents in, pet ether fraction of Wrightia tinctoria seed. Phcog J 7(4):249-253. https://doi.org/10.5530/pj.2015.4.7

29. Tadesse L, Mekbib F, Wakjira A, Tradele Z (2018) Multivariate analysis of genetic diversity in The Ethiopian garden cress (Lepidium sativum L.) genotypes. J Exp Agric Int 27(3):1-16. https ://doi.org/10.9734/JEAl/2018/43983

30. Umesha SS, Naidu KA (2013) Antioxidants and antioxidant enzymes status of rats fed on n-3 PUFA rich Garden cress (Lepidium sativum L.) seed oil and its blended oils. J Food Sci Technol 52(4):1993-2002. https://doi.org/10.1007/s13197-013-1196-3

31. Zheljazkov VD, Vick BA, Baldwin BS, Buehring N, Astatkie T, Johnson $B$ (2009) Oil content and saturated fatty acids in sunflower as a function of planting date, nitrogen rate and hybrid. Agron J 101(4):103-111. https://doi.org/10.2134/agronj2009.0011

Publisher's Note Springer Nature remains neutral with regard to jurisdictional claims in published maps and institutional affiliations. 